\title{
Frank Schleicher, Timo Stickler, Udo Hartmann (eds.), Iberien zwischen Rom und Iran. Beiträge zur Geschichte und Kultur Transkaukasiens in der Antike (Oriens et Occidens, Bd. 29), Franz Steiner Verlag 2019, 343 pp., 11 b/w plates + map, ISBN 978-3-515-12276-4
}

In Antiquity, the Caucasus Mountains represented a barrier between the lands on either side that was difficult to conquer, since there were only few roads traversing the range. Understandably, therefore, the ability to wrest control over these routes was therefore vital for the states lying in the immediate vicinity of the Caucasus and the great empires with an interest in the region. Gaining control over them would mean having influence on the course of events in a number of areas in the region. Thanks to historical sources, we know a considerable amount about the history of the rivalry between Rome and the Arsacids and Byzantium with the Sasanians for influences in Armenia and Caucasian Iberia. The political and military dimension of this rivalry has long been of interest to scholars. Only recently, however, have the ancient states of the Caucasus begun to be the subject of large-scale research projects aiming to study their history and cultural heritage more precisely on the basis of local sources. The first results of one such project have now seen the light of day as the proceedings of the conference "Iberien zwischen Rom und Iran von Pompeius bis Herakleios," which took place at the University of Jena between 7 and 9 July, 2016. This conference was organised as part of the project "Iberien in der Spätantike - Ein Kleinstaat im Spannungsfeld zweier Imperien," implemented from 2015 by a group of scholars from Jena in collaboration with colleagues from Ilia State University, Tbilisi.

The subject of the conference was the political history and problems of cultural and religious history of Caucasian Iberia in the period from the first century BCE until the sixth century CE. Also presented were the results of archaeological work at sites of great significance for the beginnings of Christian architecture in Iberia. The topics that the conference participants concentrated on are reflected in the order of the proceedings. The first part ("Historische Aspekte") focuses on the political history of Iberia. It consists of seven articles whose authors analyse various episodes concerning Rome's contacts with Iberia and the treatment of Iberian history in the works of Roman authors; they show the problems caused by the history of Iberia in Iberian historiographical tradition; the place of the Caucasus in the politics of the Arsacids and Sasanians, and the evolution of the positions of the rulers of these dynasties regarding the region; the dynastic relations between the dynasties ruling Armenia and Iberia; the activity (or lack thereof) of late Roman diplomacy in the Caucasus, and the picture of Byzantine-Persian mili- 
tary actions in Lazika in the period according to Procopius (B. Bäbler, "Pompeius im Kaukasus," pp. 15-24; U. Hartmann, "Iberien in der Historia Augusta," pp. 25-68; F. Schleicher, "Die Chronologie der k'art "velischen Könige und das Ende des iberischen Königtums,” pp. 69-98; H. Börm, "Die Grenzen des Größkönigs? Überlegungen zur arsakidisch-sasanidischen Politik gegenüber Rom,” pp. 99-122; G. Traina, "Dynastic Connections in Armenia and Iberia: Further Reflections on the Greek Inscriptions from Bagineti (SEG 52, no 1509-1510)," pp. 123-128; H. Andres, "Die Bestrafung der Misimianen," pp. 129-152; T. Stickler, "Der transkaukasische Kriegsschauplatz bei Prokop," pp. 153-177).

The second part of the proceedings ("Kulturelle und religiöse Aspekte") comprises articles on an array of issues related to the Christianisation of Iberia and the consequences of this decision. Several of them concern matters of a philological and historicalliterary nature. Their authors reflect upon the linguistic situation in the region, but also the picture of Iberia in Armenian literature and literary evidence of the presence of the Iberians in Late Antique Palestine. It is worth noting that the reflections on the Christianisation of Iberia often feature the subject of Armenia's influence on this process and the numerous links between the two lands in the early phase of their Christianisation. Historical-cultural and historical-political aspects of the process of Christianisation of Iberia are presented in two articles (S. H. Rapp Jr., "The Christianization of Eastern Georgia: Cross-Cultural and Pan-Regional Perspectives," pp. 181-199; J. Rist, "Nino versus Gregor. Die Christianisierung Iberiens im Vergleich zu Armenien,” pp. 201-221; J. Niehoff-Panagiotidis, "Griechisch, Aramäisch oder was? Identität und Schriftlichkeit im Nahen Osten zu frühbyzantinischer Zeit," pp. 223-238; A. Drost-Abgarjan, "Das Bild der Iberer in der armenischen Literatur im 5.-7. Jahrhundert," pp. 239-255; T. Gnoli, "A Notable Palmyrénien: Septimius Vorōd," pp. 257-275; C. Horn, "Die Georgier und das Heilige Land. Literarische und historische. Literarische und historische Elemente einer spätantiken Beziehung," pp. 277-293; J.-M. Kötter, "Bekenntnis als Mittel der Bündnispolitik? Überlegungen zur frühen kirchlichen Entwicklung in Iberien,” pp. 295-306).

The third part, focusing on archaeological evidence associated with the Christianisation of Iberia ("Archäologische Aspekte"), consists of two articles. The author of the first one presents the results of archaeological studies carried out over a number of years in Qvareli, in which the remains of one of the most important cities of the ancient Kingdom of Iberia, Nekresi, can be found (N. Baxtaże, "The Oldest Basilicas Revealed in Former City of Nekresi: Hypotheses on the Architectural Design of the First Georgian Christian Churches," pp. 309-322). Apart from a small circle of specialists, the results of these studies are not widely known, and therefore their presentation by the Lirector of the expedition which conducted the excavations is particularly noteworthy. This is because in the light of these digs, previously popular opinions on the earliest sites of Christian worship in Iberia and the cultural phenomena accompanying the introduction of Christianity to this Caucasian state demand substantial revision. Not only did the archaeologists discover the remnants of two large basilicas (the Čabukauri Basilica (pp. 310-314) and the Določopi Basilica (pp. 314-317)), the remains of pagan temples and other smaller sacred Christian edifices as well as various types of utility buildings and graves, but more importantly, they were able to determine quite precisely the time and order in which the 
various structures were built. We therefore now know that the oldest sacred buildings in Iberia were constructed as early as the late fourth or early fifth century CE. These include the Čabukauri Basilica, built on the ruins of the pagan temple (pp. 312-314). The buildings from the same period also include a church found underneath the Določopi Basilica, on whose remains it was built (pp. 316-317). The author of the second article in this part of the book presents numerous sites and buildings connected to Christian worship in Kvemo Kartli (Lower Iberia) from Late Antiquity and the Early Middle Ages (A. Plontke-Lüning, "Von Dmanisi nach Bolsini. Ein alter Pilgerweg in Kvemo Kartli," pp. 323-334).

A rather small number of scholars are familiar with the history of ancient Iberia. One can state with the greatest conviction that this volume of studies will introduce wider numbers of readers to numerous episodes from this land's past and to the subject of its relations with its neighbours. It is particularly worth recommending to those with an interest not only in the history of Transcaucasia, but also Byzantium, the Sasanian Iran, and Christianity as a whole in the region.

Edward Dąbrowa (Jagiellonian University in Kraków) 